\title{
RESEARCH
}

Open Access

\section{Combination of laser and human adipose- derived stem cells in repair of rabbit anal sphincter injury: a new therapeutic approach}

Arash Sarveazad ${ }^{1}$, Asrin Babahajian², Abazar Yari ${ }^{3}$, Chris K. Rayner ${ }^{4,5}$, Marjan Mokhtare ${ }^{1}$, Arash Babaei-Ghazani ${ }^{6}$, Shahram Agah', Bahar Mahjoubi ${ }^{1}$, Jebreil Shamseddin ${ }^{7}$ and Mahmoud Yousefifard ${ }^{8^{*}}$ (D)

\begin{abstract}
Background: Anal sphincter injury leads to fecal incontinence. Based on the regenerative capability of laser and human adipose-derived stem cells (hADSCs), this study was designed to assess the effects of co-application of these therapies on anal sphincter recovery after injury.

Design: Male rabbits were assigned to equal groups $(n=7)$ including control, sphincterotomy, sphincterotomy treated with laser $\left(660 \mathrm{~nm}, 90 \mathrm{~s}\right.$, immediately after sphincterotomy, daily, 14 days), hADSCs $\left(2 \times 10^{6}\right.$ hADSCs injected into injured area of the sphincter immediately after sphincterotomy), and laser + hADSCs. Ninety days after sphincterotomy, manometry and electromyography were performed, sphincter collagen content was evaluated, and Ki67, myosin heavy chain (MHC), skeletal muscle alpha-actin (ACTA1), vascular endothelial growth factor A (VEGFA), and vimentin mRNA gene expression were assessed.

Results: The laser + hADSCS group had a higher resting pressure compared with the sphincterotomy $(p<0.0001)$, laser $(p<0.0001)$, and hADSCs $(p=0.04)$ groups. Maximum squeeze pressure was improved in all treated animals compared with the sphincterotomized animals $(p<0.0001)$, without a significant difference between treatments $(p>0.05)$. In the laser + hADSCs group, motor unit numbers were higher than those in the laser group $(p<0.0001)$ but did not differ from the hADSCs group $(p=0.075)$. Sphincterotomy increased collagen content, but the muscle content $(p=0.36)$ and collagen content $(p=0.37)$ were not significantly different between the laser + hADSCs and control groups. Laser + hADSCs increased ACTA1 $(p=0.001)$ and MHC $(p<0.0001)$ gene expression compared with laser or hADSCs alone and was associated with increased VEGFA $(p=0.009)$ and Ki67 mRNA expression $(p=0.01)$ and decreased vimentin mRNA expression $(p<0.0001)$ compared with laser.
\end{abstract}

Conclusion: The combination of laser and hADSCs appears more effective than either treatment alone for promoting myogenesis, angiogenesis, and functional recovery after anal sphincterotomy.

Keywords: Fecal incontinence, Lasers, Mesenchymal stem cells

\footnotetext{
* Correspondence: yousefifard.m@iums.ac.ir; yousefifard20@gmail.com

${ }^{8}$ Physiology Research Center, Iran University of Medical Sciences, Tehran, Iran Full list of author information is available at the end of the article
}

C The Author(s). 2019 Open Access This article is distributed under the terms of the Creative Commons Attribution 4.0 International License (http://creativecommons.org/licenses/by/4.0/), which permits unrestricted use, distribution, and reproduction in any medium, provided you give appropriate credit to the original author(s) and the source, provide a link to the Creative Commons license, and indicate if changes were made. The Creative Commons Public Domain Dedication waiver (http://creativecommons.org/publicdomain/zero/1.0/) applies to the data made available in this article, unless otherwise stated. 


\section{Introduction}

The anal sphincter provides both resting contractile tone and voluntary contraction for its role in closing the anal canal and maintaining fecal continence [1]. Anal sphincter injury caused by trauma (e.g., during vaginal delivery) or surgical sphincterotomy can lead to fecal incontinence (FI) [2], a condition that affects women (8.9\%) more than men $(7.7 \%)$, and is associated with social isolation, low self-esteem and depression, and impaired quality of life [3, 4]. Surgical repair of the anal sphincter [5] has satisfactory short-term outcomes, but recurrence is common over the longer term $[6,7]$. Other treatments such as artificial sphincters or mesh may carry complications including discomfort, infection, and implant failure [8]. Bulking agents are prone to displacement, emboli formation, and granulation $[9,10]$. Therefore, reconstitution of muscle tissue, utilizing stem cells that are capable of differentiating into various cell types, would appear an ideal strategy to improve long-term outcomes in FI. Human adipose-derived stem cells (hADSCs) are an easily accessible and abundant source of the stem cells $\left(10^{6}\right.$ cells/g of fat tissue) [11], with a high proliferative rate $[12,13]$. The paracrine effect of hADSCs leads to anti-apoptotic, anti-inflammatory, anti-fibrotic and immunomodulatory, and angiogenesis properties [14] that cause host tissue muscle regeneration. On the other hands, their capability to differentiate into muscle fibers has been demonstrated in vitro $[12,15]$.

Silent satellite cells in the basement membrane of muscle fibers play an important role in muscle regeneration. A low-level laser (LLL) can activate these cells preparing the division phase and finally contributing to the muscular repair process $[16,17]$. Furthermore, LLL has anti-apoptotic properties [18] and can activate fibroblasts to FGF and IGF-1 secretion [19, 20], contributing to the repair and regeneration of muscle tissue. Therefore, co-application of hADSCs and LLL may be an effective strategy for anal sphincter repair. This study was designed to assess the effects of each therapy individually, and when applied together, on anal sphincter recovery and function after experimental injury.

\section{Materials and methods}

\section{Animals}

Thirty-five male albino New Zealand rabbits weighing 2.5-3.0 kg were purchased from Pasteur Institute of Iran. Animals were kept in standard conditions of ambient temperature $\left(21 \pm 3{ }^{\circ} \mathrm{C}\right)$ and 12 -h dark-light cycle, with free access to fresh water and food based on the ethical rules for care and handling of laboratory animals of Iran University Ethical Committee, code 94-04-182-27064. Animals were randomly assigned to five equal groups $(n=7)$ :
1- Control group: animals received no intervention

2- Sphincterotomy group: animals underwent sphincterotomy without any other intervention

3- Laser group: animals underwent sphincterotomy and low-level laser irradiation

4- hADSCs group: animals underwent sphincterotomy and $2 \times 10^{6}$ hADSC injection into the injured anal sphincter

5- Laser + hADSCs group: animals underwent sphincterotomy and hADSC injection into the injured anal sphincter followed by low-level laser irradiation

\section{Isolation and immunophenotyping of hADSCs}

Human subcutaneous abdominal adipose tissue was taken from female candidates aged 25 to 35 years old and transferred to a sterile dish containing FBS, DMEM/Ham's F-12 $10 \%$, and streptomycin/penicillin (P/S) 5\%. Isolation of hADSCs followed a protocol described for our previous studies [21-24]. In brief, fat tissue was rinsed twice in $\mathrm{P} / \mathrm{S}$ $1 \%$ prepared with warm PBS to remove vessels and connective tissue. The samples were then transferred to 50-ml tubes containing collagenase $0.1 \%$ and BSA $1 \%$ prepared in warm PBS for $60 \mathrm{~min}$ to achieve tissue digestion. After a 5-min centrifugation in $12,000 \mathrm{rpm}$ to remove $\mathrm{RBCs}$, the resulting pellet was suspended with RBC lysis buffer for $10 \mathrm{~min}$ and re-centrifuged. Finally, after a PBS wash, the cells were cultured to DMEM/Ham's F-12 in FBS $10 \%$ and P/S $1 \%$ medium. The cell flasks were kept in an incubator at $37{ }^{\circ} \mathrm{C}$ with $5 \% \mathrm{CO}_{2}$ and $98 \%$ humidity, and in the third passage, hADSCs were characterized with flow cytometry $\left(\mathrm{CD} 29^{+}\right.$, $\mathrm{CD}_{3}{ }^{+}, \mathrm{CD}_{105}{ }^{+}, \mathrm{CD} 34^{-}$, and $\mathrm{CD} 45^{-}$) (Additional file 1: Figure S1).

\section{Sphincterotomy model}

Our model was selected to achieve the equivalent of a grade 4 anal sphincter tear [tear of the external anal sphincter (EAS), internal anal sphincter (IAS), and anal mucosa] according to Sultan's classification [25]. Under general anesthesia with ketamine $(80 \mathrm{mg} / \mathrm{kg})$ and xylazine $(10 \mathrm{mg} / \mathrm{kg})$, animals were put in the lithotomy position. The perineal skin and anus were thoroughly washed with povidone iodine and normal saline solutions, and a 1-cm incision was made with a surgical blade in the left side of the anal sphincter.

\section{Labeling of hADSCs}

Before transplantation in the third passage, hADSCs were suspended in $1 \mathrm{ml}$ PBS, and $5 \mu \mathrm{l}$ of Dil solution (containing $50 \mu \mathrm{g}$ Dil powder in $50 \mu \mathrm{l}$ DMSO) was added and the cells were incubated for $5 \mathrm{~min}$ at $37^{\circ} \mathrm{C}$ with $5 \% \mathrm{CO}_{2}$ and $98 \%$ humidity, and then for $20 \mathrm{~min}$ at $8-10{ }^{\circ} \mathrm{C}$. 


\section{hADSC administration and LLL irradiation}

In the hADSCs group, $2 \times 10^{6} \mathrm{hADSCs} / 40 \mu \mathrm{l}$ PBS was injected immediately after sphincterotomy into the injured sphincter within 2 min using a Hamilton syringe equipped with a 25 -gauge needle. In the LLL group, a CW laser diode with 660-nm wavelength and 100-W power (Heltschl, model ME-TL10000-SK) was mounted on a metal rod to maintain a distance of $2 \mathrm{~cm}$ between the radiation source and the target site. Irradiation commenced (90 s) immediately after sphincterotomy and hADSC transplantation and was repeated daily for 14 days.

\section{Manometry}

Ninety days after sphincterotomy, anal sphincter manometry was performed by means of a standard 4.7$\mathrm{mm}$ anorectal catheter and a pressure transducer (Mui Scientific, Canada) by an operator blinded to the treatment allocation. The probe was inserted into the animal rectum without any anesthesia induction, and the balloon baseline pressure was established; then, the probe was withdrawn at a constant rate of $0.05 \mathrm{~cm} / \mathrm{s}$, and the sphincter pressure profile (resting and maximum squeeze pressures) was recorded. When the probe was inserted into the animal rectum, we stimulate the external anal sphincter with tingling (natural stimulus) and squeezing pressure was recorded. The procedure was repeated at least three times for each animal.

\section{Electromyography}

Electromyography (EMG) was also performed 90 days after sphincterotomy using a Synergy on Nicolet EDX system (Natus Medical Corporation, USA), with adhesive electrodes applied to a $0.02-\mathrm{mm}^{2}$ recording area in the hairless part of the rabbit's earlobe, with a disposable needle (30 gauge, $0.3-\mathrm{mm}$ diameter, $25 \mathrm{~mm}$ long; Ambu Copenhagen, Denmark). The animal was fixed in the lithotomy position without anesthesia or muscle relaxants. The EMG needle was inserted perpendicularly into the anal skin to a depth of $5 \mathrm{~mm}$, adjacent to the mucosal border. The EMG sweep and sensitivity were set at $10 \mathrm{~ms} / \mathrm{cm}$ and $100-200 \mathrm{mV}$, respectively. Afterwards, the number of motor unit action potentials (MUAPs) was assessed within a 20-s time window.

\section{Histological assessment}

Ninety days after sphincterotomy, three randomly selected animals from each group were sacrificed with intracardial perfusion with $4 \%$ paraformaldehyde under deep anesthesia $(80 \mathrm{mg} / \mathrm{kg}$ ketamine and $10 \mathrm{mg} / \mathrm{kg}$ xylazine). The anal sphincter was excised intact, fixed overnight with $4 \%$ paraformaldehyde, set in paraffin, and cut into $10-\mu \mathrm{m}$ transverse serial sections. The remaining four animals in each group were deeply anesthetized in the lithotomy position, and the anal sphincter was excised and transferred fresh into cold PBS then to a $80^{\circ} \mathrm{C}$ freezer for ensuing real-time PCR technique.

\section{Mallory's trichrome staining and quantitative assay of muscle and collagen content}

Three sections from each animal ( $n=3$ in each group) were selected and stained with Mallory's trichrome method. After imaging under a light microscope $(\times 40)$, the area occupied by Mallory's trichrome stain (blue color) was measured using ImageJ software (Fiji 1.46), and the percentage of the total area positive for collagen and muscle was calculated by dividing Mallory's trichrome area by the total area of the section [22].

\section{Immunohistochemistry}

Ki67 primary antibody (Thermo Fisher Scientific, MA5-14520), myosin heavy chain (MHC) primary antibody (Sigma, M4276), skeletal muscle alpha-actin (ACTA1) primary antibody (Sigma, A5228), vascular endothelial growth factor A (VEGFA) primary antibody (Abcam, ab1316), and vimentin primary antibody (Sigma, V6630) were used. Alexa Fluor 594 goat anti-mouse IgG (Biolegend, 405326) was used to detect the primary antibody. Briefly, after antigen retrieval (citrate buffer $\mathrm{pH}=6$, temperatures below the boiling point, $10 \mathrm{~min}$ ) and washing (PBS three times), a 15-min incubation with $\mathrm{H}_{2} \mathrm{O}_{2} 10 \%$ diluted in methanol was performed. After washing (PBS three times), blocking in goat serum $10 \%$ (Sigma, USA) for $30 \mathrm{~min}$ at $37^{\circ} \mathrm{C}$ was performed. After incubation of the samples with the primary antibody ( $24 \mathrm{~h}$ at $4{ }^{\circ} \mathrm{C}$, humidified environment) and washing (PBS three times), the samples were incubated (2 $\mathrm{h}$ in the dark, $37^{\circ} \mathrm{C}$, humidified environment) with the secondary antibody. Finally, DAPI staining was performed to stain the cell nuclei. The slides were photographed using a fluorescence microscope equipped with a camera $(\times 10)$.

\section{Gene expression analysis by real-time PCR}

The total RNA was extracted using a RNA extraction kit (EURx Company, Poland) followed by reverse transcription of RNA using EURx cDNA synthesis kits and a random hexamer primer. Using the Cybergreen kit (Qiagen Company, USA), the primers of ACTA1, glyceraldehyde-3-phosphate dehydrogenase (GAPDH), MHC, VEGFA, vimentin, and Ki67 were used to analyze the gene expression using ABI StepOnePlus $^{\text {TM }}$ Real-Time PCR (Applied Biosystems Company, USA). Gene expression data were normalized using the GAPDH gene as an internal control. The 
sequence of primers is shown in a supplementary file (Additional file 1: Table S1).

\section{Statistical analysis}

Data were analyzed in SPSS 21.0 and presented as means and standard errors. Two-way repeated measures ANOVA was used to compare the mean of the manometric findings. One-way ANOVA was used to assess the histological assays. Bonferroni post hoc was applied in all analyses and $p<0.05$ was considered significant.

\section{Results}

\section{Resting pressure and maximum squeeze pressures}

As shown in Fig. 1, sphincterotomy led to a significant decrease in resting pressure $(\mathrm{df}=8,60 ; F=81.6 ; p<$ 0.0001). Three months after sphincterotomy, the resting pressure significantly increased in the hADSCs $(29.0 \pm$ $1.2)$, laser $(21.7 \pm 0.8)$, and laser + hADSCs $(35.0 \pm 1.4)$ groups $(p<0.0001)$ but did not reach the level of the non-sphincterotomy control $(43.3 \pm 0.8)$ group $(p<0.01)$. The resting pressure in the hADSCs group was higher than that in the laser-treated group $(p=0.05)$. In addition, it was higher in the laser + hADSCs group than in either the laser $(p<0.0001)$ or hADSCs $(p=0.04)$ groups.

The maximum squeeze pressure in sphincterotomized animals $(10.0 \pm 0.6)$ was dramatically decreased $(\mathrm{df}=8,60$; $F=400.3 ; p<0.0001)$. After 3 months, maximum squeeze pressure increased in the laser $(101.1 \pm 1.4)$, hADSCs $(107.4 \pm 1.2)$, and laser + hADSCs $(108.2 \pm 2.2)$ groups $(p<0.0001)$ but did not reach to controls $(127.4 \pm 1.2)$ $(p<0.0001)$. No significant difference in maximum squeeze pressure was seen between the laser $(p=0.06)$, hADSCs $(p>0.99)$, and laser + hADSCs groups (Fig. 1).

\section{Motor unit numbers}

EMG testing showed motor unit number reduction in the sphincterotomy group ( $\mathrm{df}=4, F=280.4 ; p<0.0001)$. The laser (8.1 $\pm 0.7 ; p<0.0001)$, hADSCs $(16.6 \pm 0.7 ; p<$ $0.0001)$, and laser + hADSCs groups $(20.0 \pm 2.2 ; p<$ $0.0001)$ displayed substantially more motor units than the sphincterotomy group $(1.0 \pm 0.2 ; p<0.0001)$, with a higher number in the hADSCs $(p<0.0001)$ and laser + hADSCs $(p<0.0001)$ groups than in the laser group, without any difference between hADSCs and laser + hADSCs $(p=0.075)$ (Fig. 1).

\section{Collagen content in the injured sphincter}

The collagen content, which was reduced in all treatment groups (92.7 $\pm 1.1 ; \mathrm{df}=4, F=162.8 ; p<0.0001)$, increased 3 months after sphincterotomy. Among the treatments, the hADSCs group $(59.4 \pm 1.9)$ had less collagen than the laser group $(66.2 \pm 1.8)(p=0.02)$. Additionally, the laser + hADSCs group $(49.9 \pm 1.5)$ showed the least collagen content, the same as the control group $(45.5 \pm 0.6)(p=0.37)$ (Fig. 2).

\section{Muscle tissue content in the injured sphincter}

The muscle content of the anal sphincter decreased 90 days after sphincterotomy in all groups $(7.3 \pm 1.0$; $\mathrm{df}=4$, $F=192.8 ; p<0.0001)$. However, it was increased in all treatment groups. Among the treatment groups, the hADSCs group $(40.6 \pm 1.9)$ had more muscle content than the laser group $(33.7 \pm 1.7)(p=0.021)$. It is worth mentioning that the muscle content of the laser + hADSCs group $(51.1 \pm 1.4)$ was not different from that of the control group (54.5 \pm 0.7$)(p=0.36)$ (Fig. 2).

\section{ACTA1 gene expression}

Real-time PCR showed that sphincterotomy $(0.03 \pm 0.005)$ decreased ACTA1 mRNA gene expression compared with the control group $(1.4 \pm 0.4)(\mathrm{df}=4, F=13.4 ; p=0.001)$. The laser + hADSCs group $(2.3 \pm 0.2)$ had increased ACTA1 expression compared with the sphincterotomy group $(p=$ 0.001 ), while there was no difference between the laser $(0.8 \pm 0.2 ; p=0.49)$ and hADSCs $(0.7 \pm 0.1 ; p=0.58)$ groups compared with the sphincterotomy group. The immunohistochemical findings followed the same pattern (Fig. 3).

\section{MHC gene expression}

Like actin gene expression, MHC mRNA gene expression was reduced with sphincterotomy $(\mathrm{df}=4, F=43.5$; $p<0.0001)$. Both the hADSCs $(1.1 \pm 0.2 ; p=0.001)$ and laser + hADSCs $(2.3 \pm 0.1 ; p<0.0001)$ groups had increased MHC expression compared with the sphincterotomy group $(0.01 \pm 0.003)$, and the laser + hADSCs group had greater MHC mRNA gene expression than either the laser $(0.4 \pm 0.05)$ or hADSCs group $(p<0.0001)$. Finally, the hADSCs group had greater MHC gene expression than the laser group $(p=0.04)$. Immunohistochemical findings followed the same pattern (Fig. 4).

\section{VEGFA gene expression}

VEGFA gene expression was reduced 3 months after sphincterotomy ( $\mathrm{df}=4, F=23.7 ; p<0.0001)$. The hADSCs $(1.3 \pm 0.2 ; p<0.0001)$ and laser + hADSCs $(0.8 \pm 0.2 ; p=$ $0.005)$ groups had increased VEGFA mRNA gene expression compared with the sphincterotomy group (0.02 \pm $0.003)$. The laser + hADSCs group had greater VEGFA expression than the laser group $(0.1 \pm 0.05 ; p=0.01)$ but did not differ from the hADSCs group $(p=0.18)$. The hADSCs group also had greater VEGFA expression than the laser group $(p<0.0001)$. Immunohistochemical findings again followed the same pattern (Fig. 5).

\section{Vimentin gene expression}

The vimentin mRNA gene expression was increased after sphincterotomy $(\mathrm{df}=4, F=13.9 ; p<0.0001)$. The 


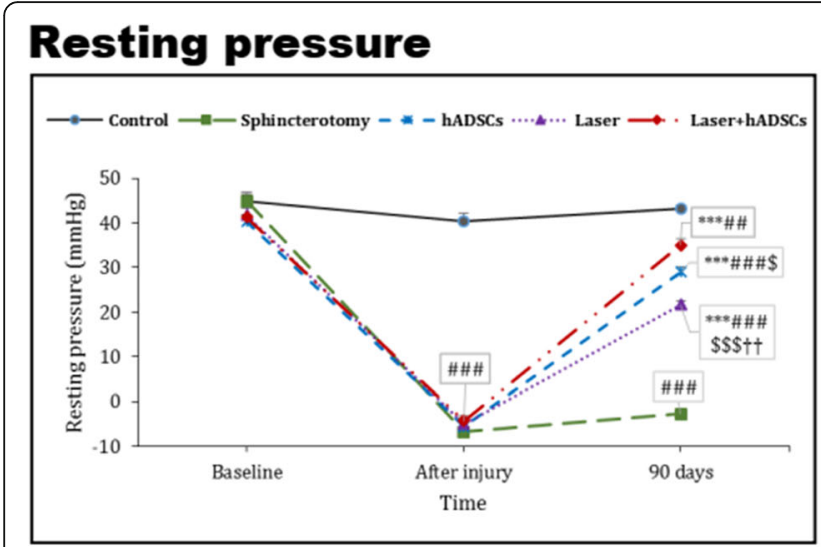

\section{EMG of control group}

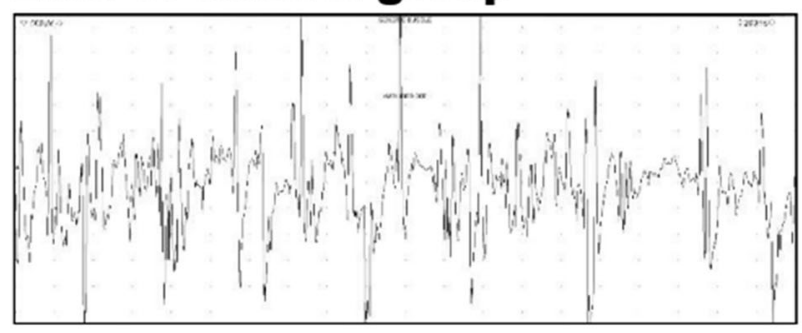

\section{EMG of Laser group}

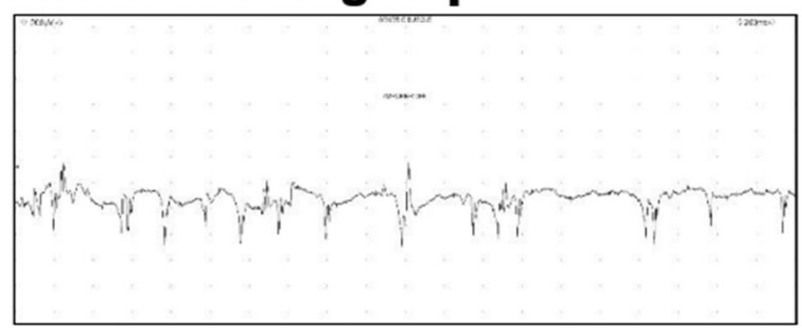

\section{EMG of Laser+hADSCs group}

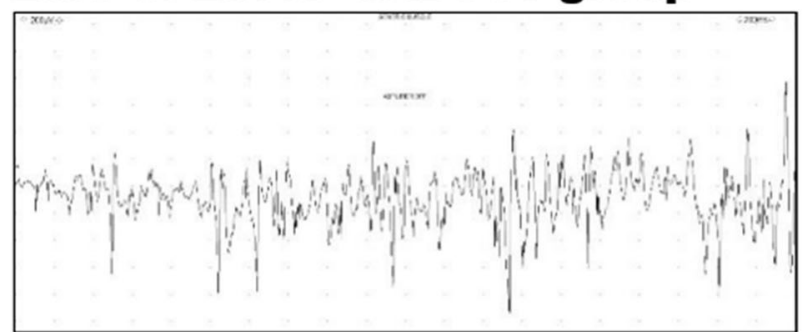

\section{Maximum squeeze pressure}

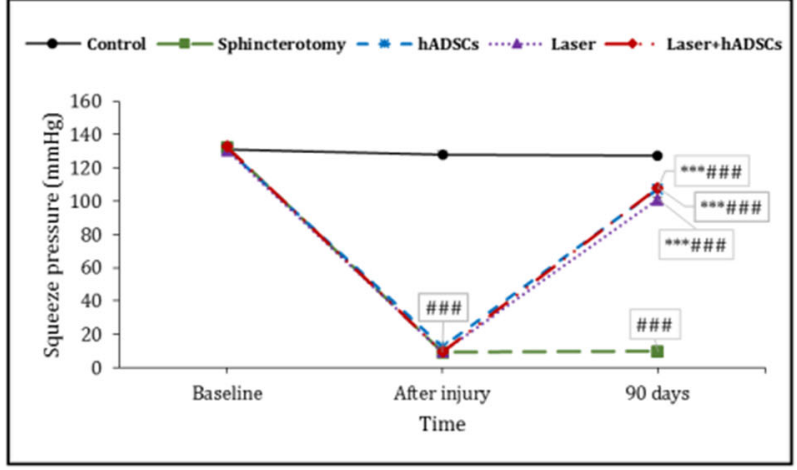

EMG of sphincterotomy group

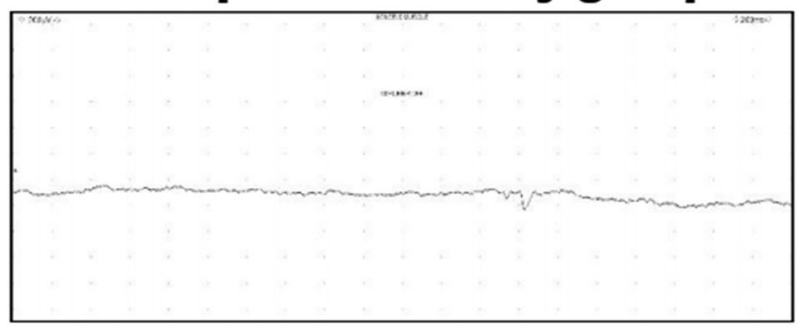

EMG of hADSCs group

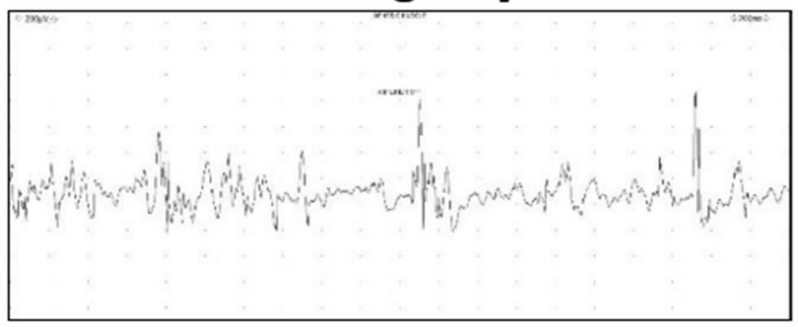

Number of motor units

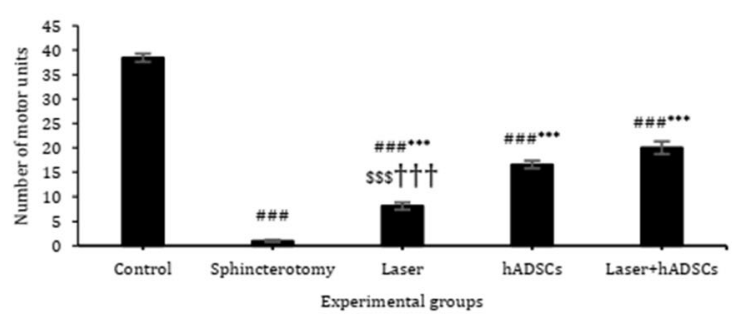

Fig. 1 Effect of laser, human adipose-derived stem cells (hADSCs), and combination of laser and hADSCs (laser + hADSCs) on resting and squeeze anal sphincter pressures and number of motor units in the anal sphincter based on electromyography. Data are presented as means \pm SEM $(n=7$ animal per group). ** Significant level at $p<0.0001$ with the sphincterotomy group. \#\#任nificant level at $p<0.0001$ with the control group (intact animals). "\#Significant level at $p<0.01$ with the control group. ${ }^{\$ \$}$ Significant level at $p<0.0001$ with the laser + hADSCs group. ${ }^{\$}$ Significant level at $p<0.05$ with the laser + hADSCs group. ${ }^{+1}$ Significant level at $p<0.01$ with the hADSCs group

hADSCs $(0.1 \pm 0.05)$, laser $(0.4 \pm 0.2)$, and laser + hADSCs $(0.1 \pm 0.03)$ groups had decreased vimentin expression compared with the sphincterotomy group $(1.6 \pm 0.3 ; p<0.0001)$; such expression was similar to the control group $(0.01 \pm 0.002 ; p>0.99)$. Immunohistochemical findings followed the same pattern (Fig. 6).
Ki67 gene expression

Although sphincterotomy $(0.005 \pm 0.001)$ had no effect on Ki67 mRNA gene expression $(p>0.99)$, the hADSCs $(2.2 \pm$ $0.6 ; p=0.007)$ and laser + hADSCs $(2.1 \pm 0.4 ; p=0.009)$ groups showed greatly increased Ki67 expression compared with controls $(0.2 \pm 0.1)(\mathrm{df}=4, F=11.4 ; p=0.001)$ (Fig. 7). 


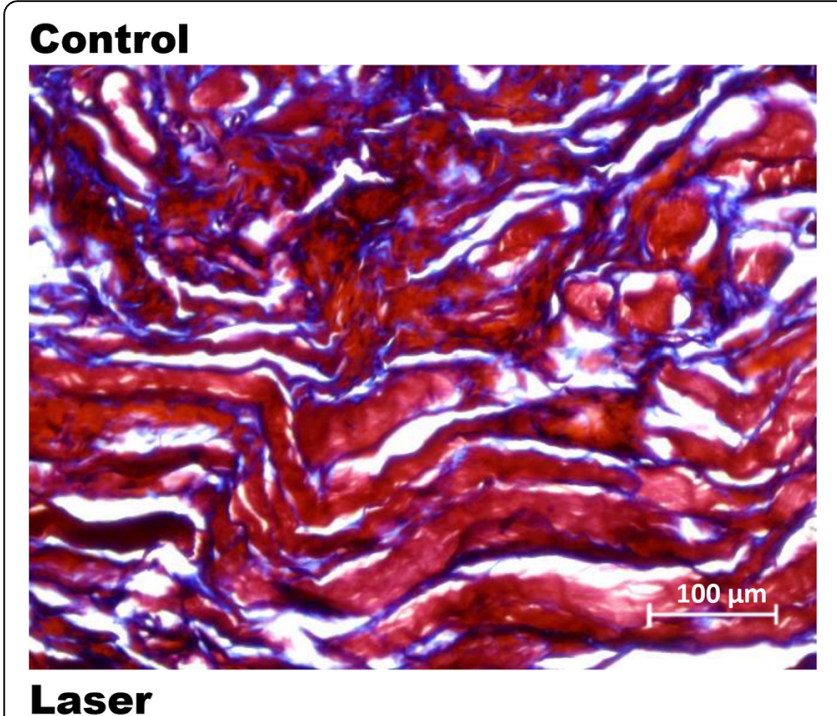

\section{Sphincterotomy}
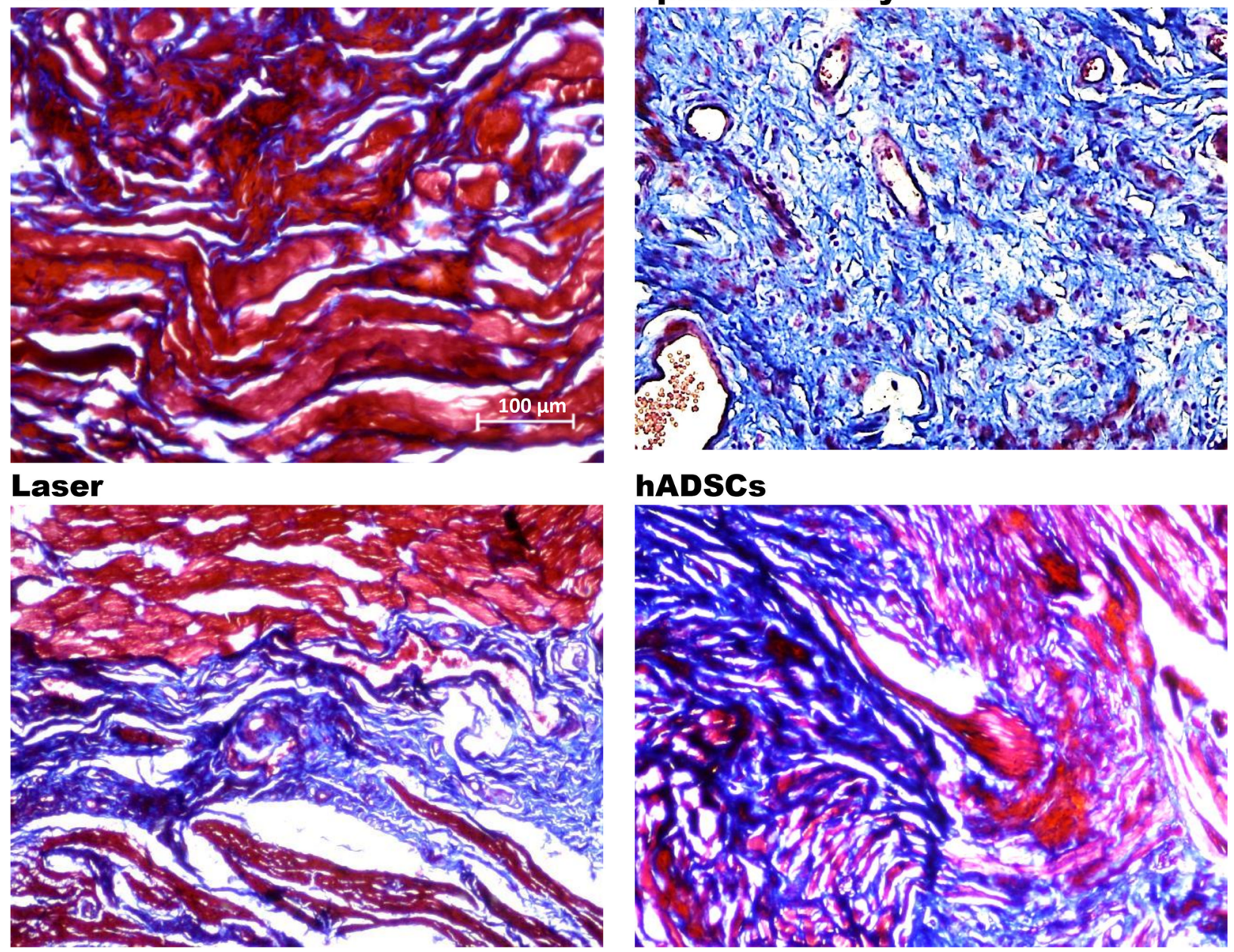

\section{Laser+hADSCs}

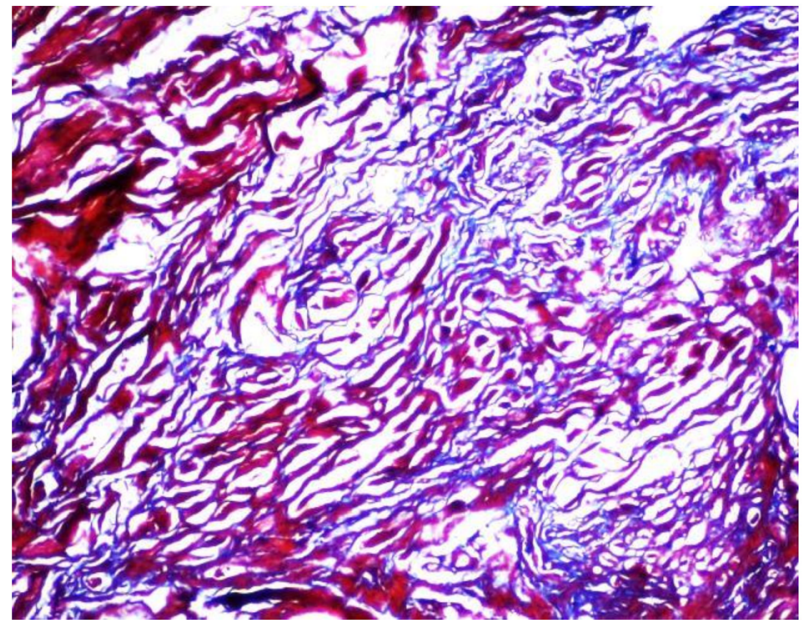

\section{hADSCs}

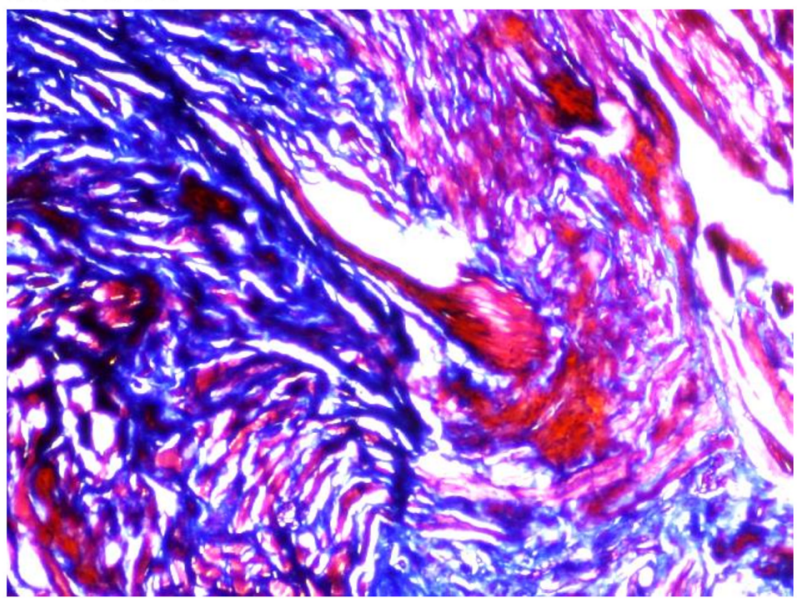

\section{Quantitative analysis}
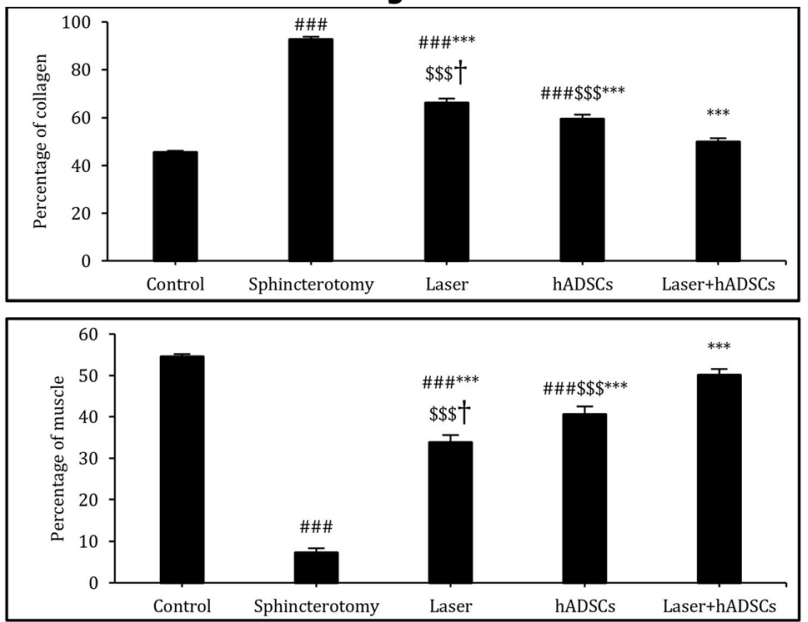

Fig. 2 Amount of collagen and muscle tissues in injury site of the external anal sphincter after laser, human adipose-derived stem cells (hADSCs), and combination of laser and hADSCs (laser + hADSCs) treatments. Data are presented as means \pm SEM ( $n=3$ animal per group). ${ }^{* *}$ Significant

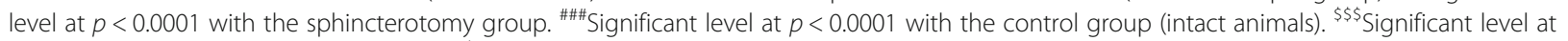
$p<0.0001$ with the laser + hADSCs group. 'Significant level at $p<0.05$ with the hADSCs group. Mallory's trichrome staining, external anal sphincter, rabbit $(\times 20)$ 


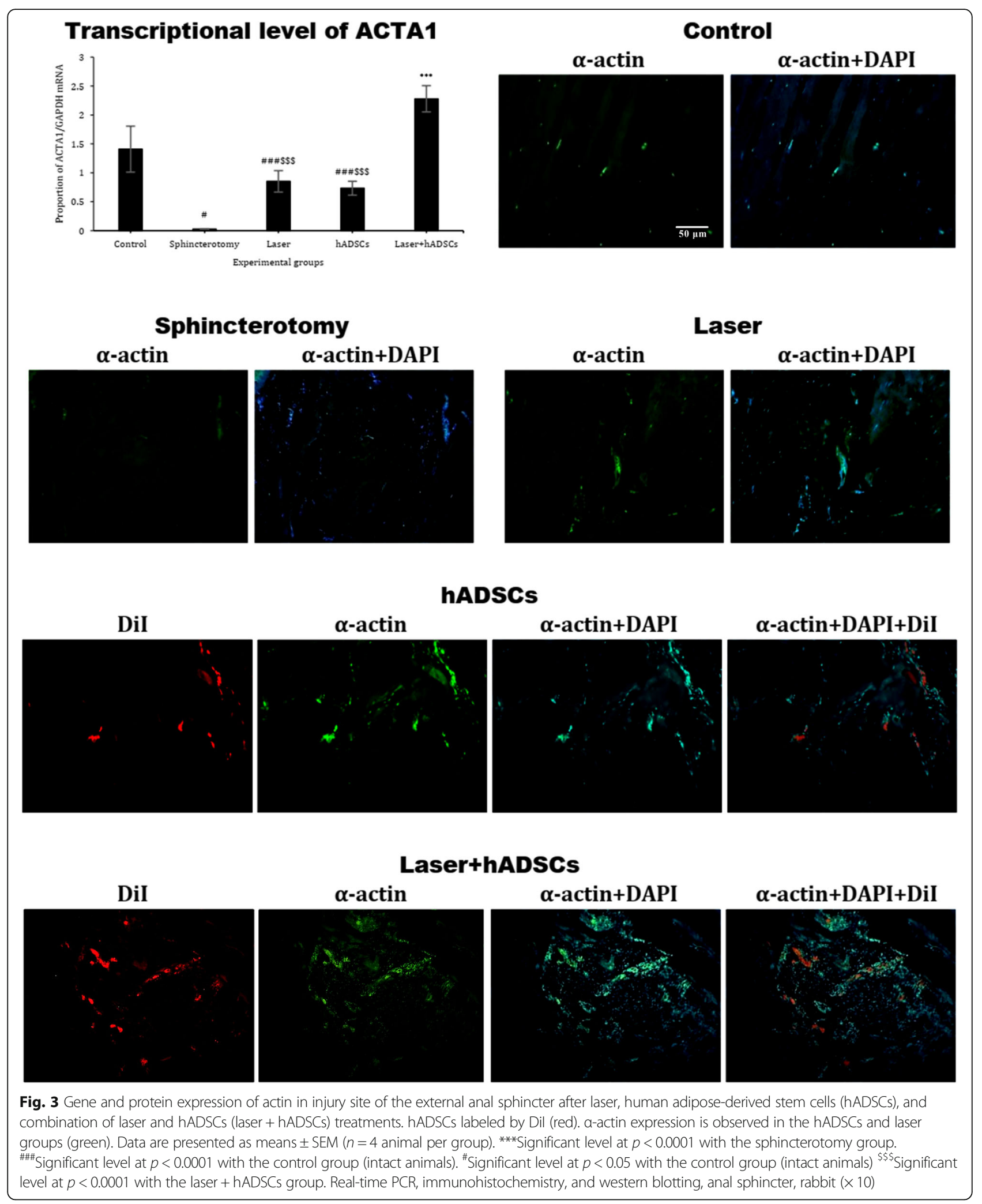

\section{Discussion}

The findings of the present study showed that the combination of laser and hADSC therapy improved anal sphincter function after experimental injury more than either treatment alone. The efficacy of the combination therapy appears to relate to an increase in 


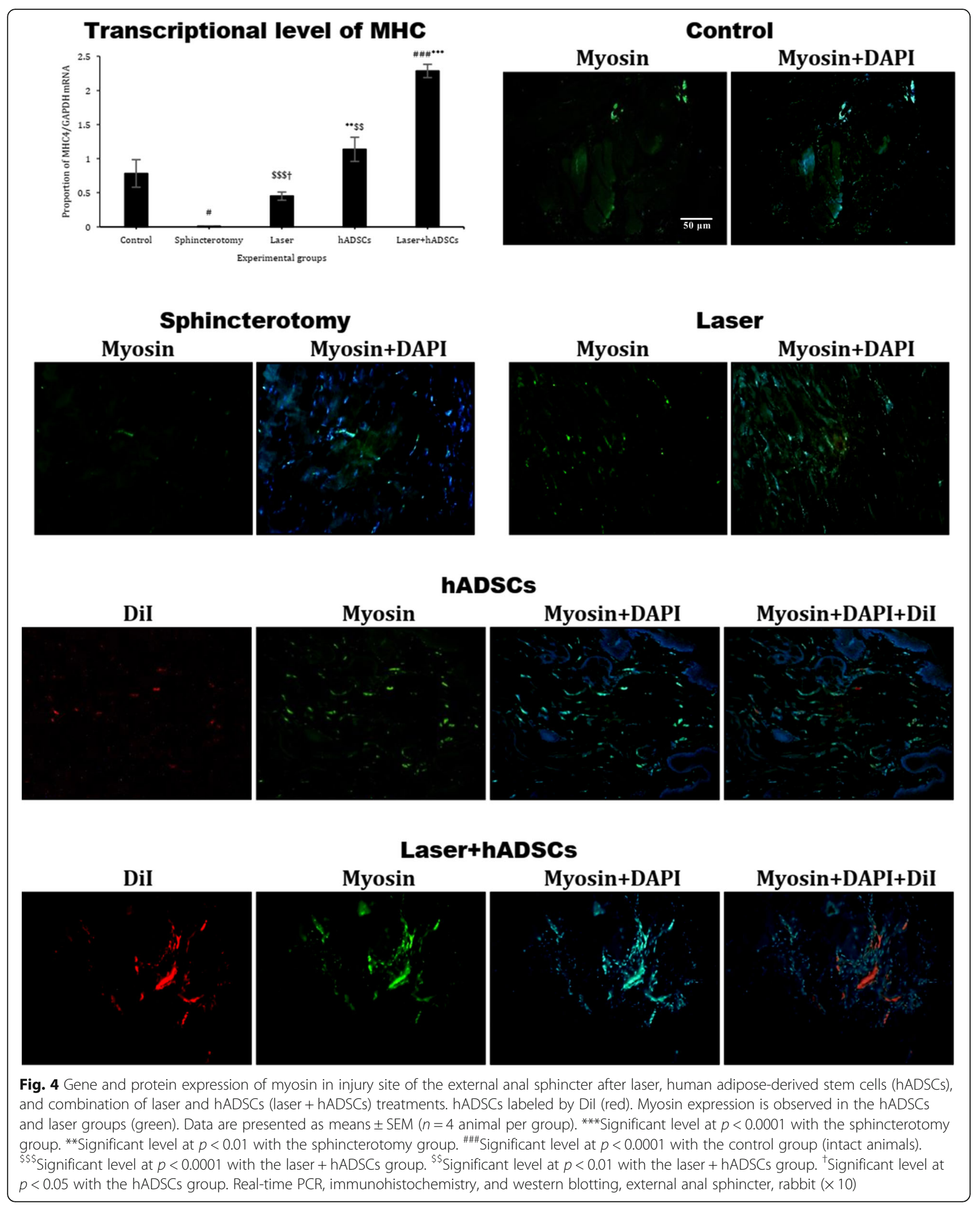




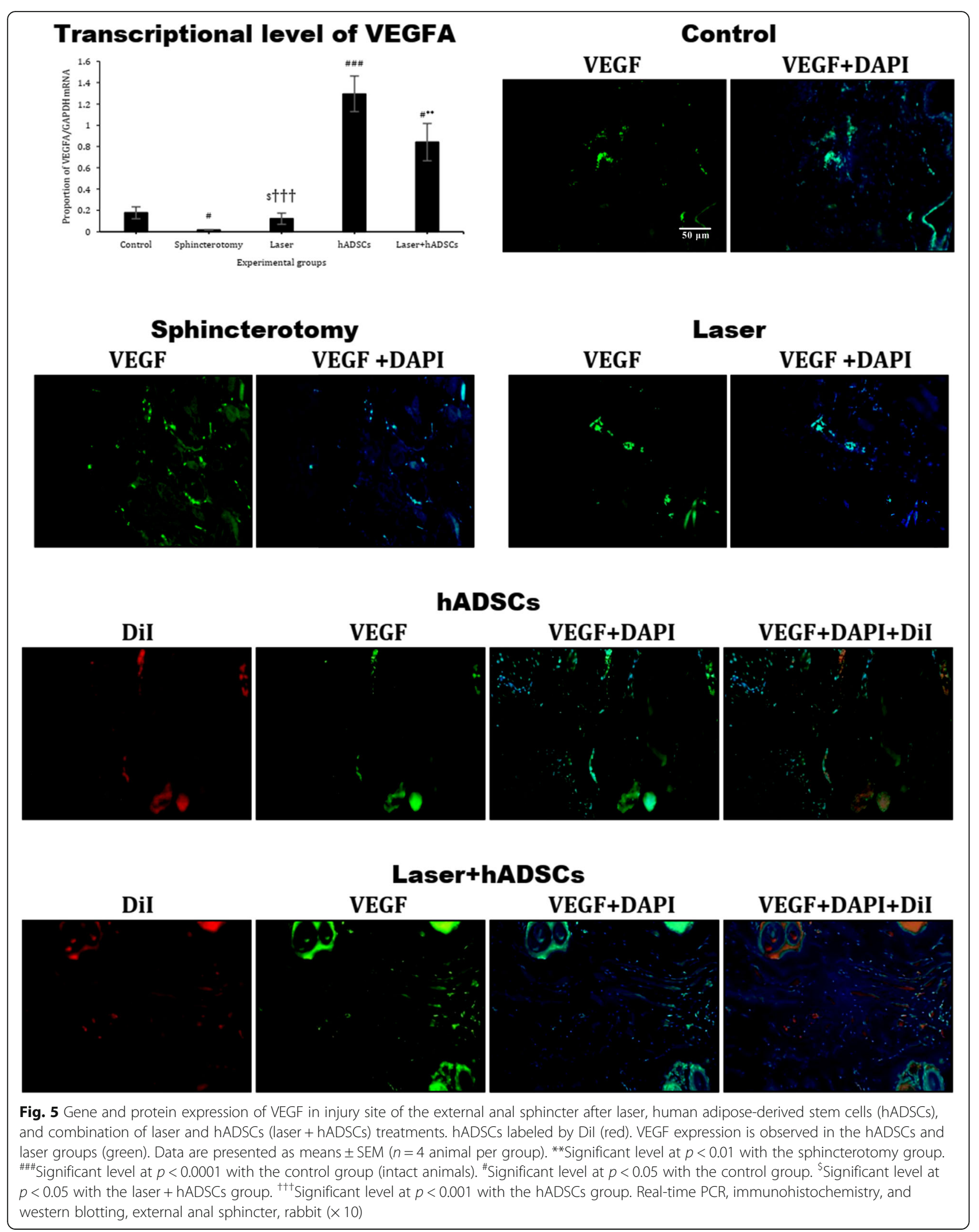




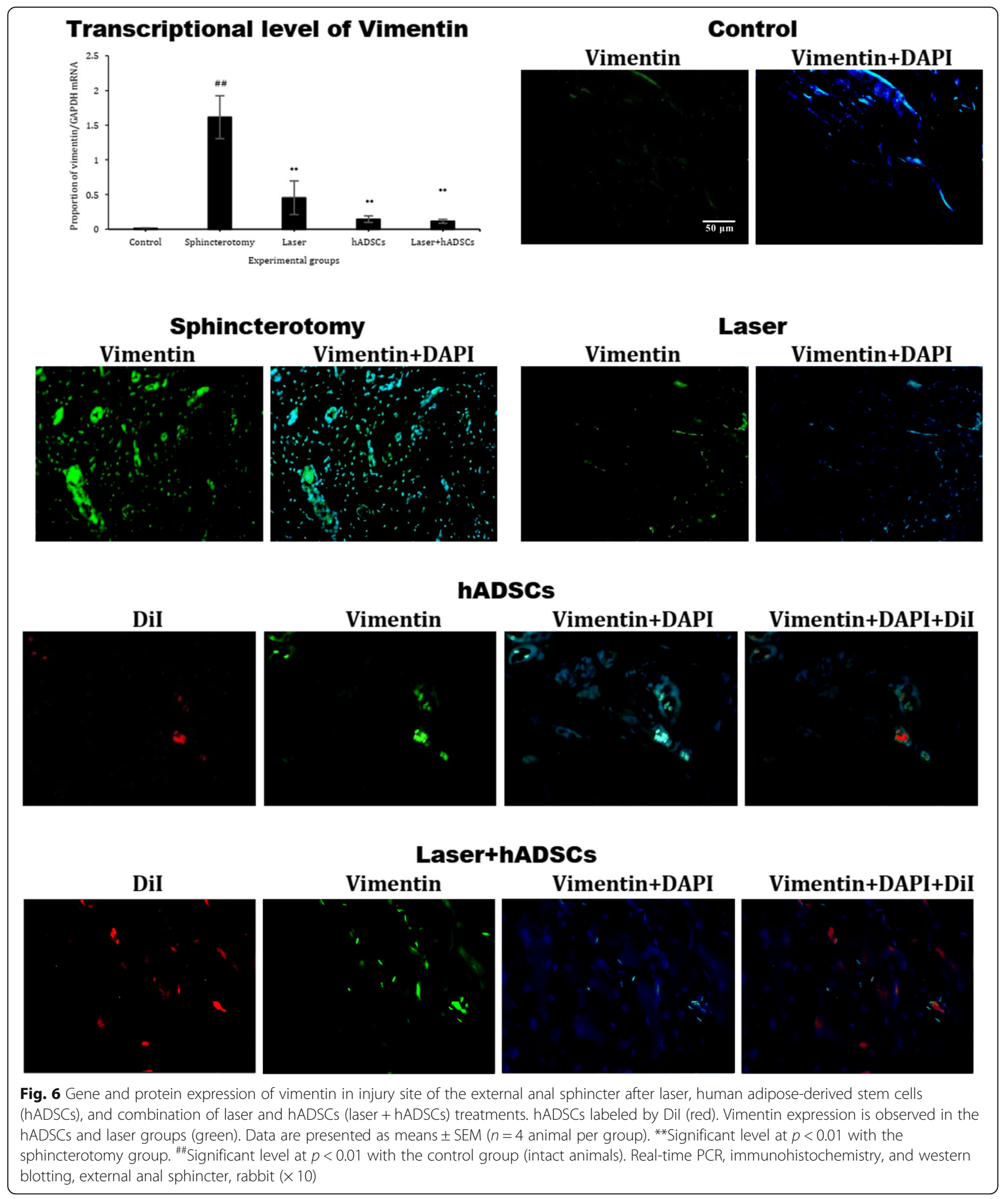

the number of motor units, decreased ratio of scar tissue to myofibril content, and an increase in the expression of myogenic, angiogenic, and proliferative markers.
The relative contribution of the EAS and IAS to resting anal pressure is typically about $15 \%$ and $85 \%$ respectively, while maximum squeeze pressure is mainly generated by the EAS [26]. In our study, both resting 


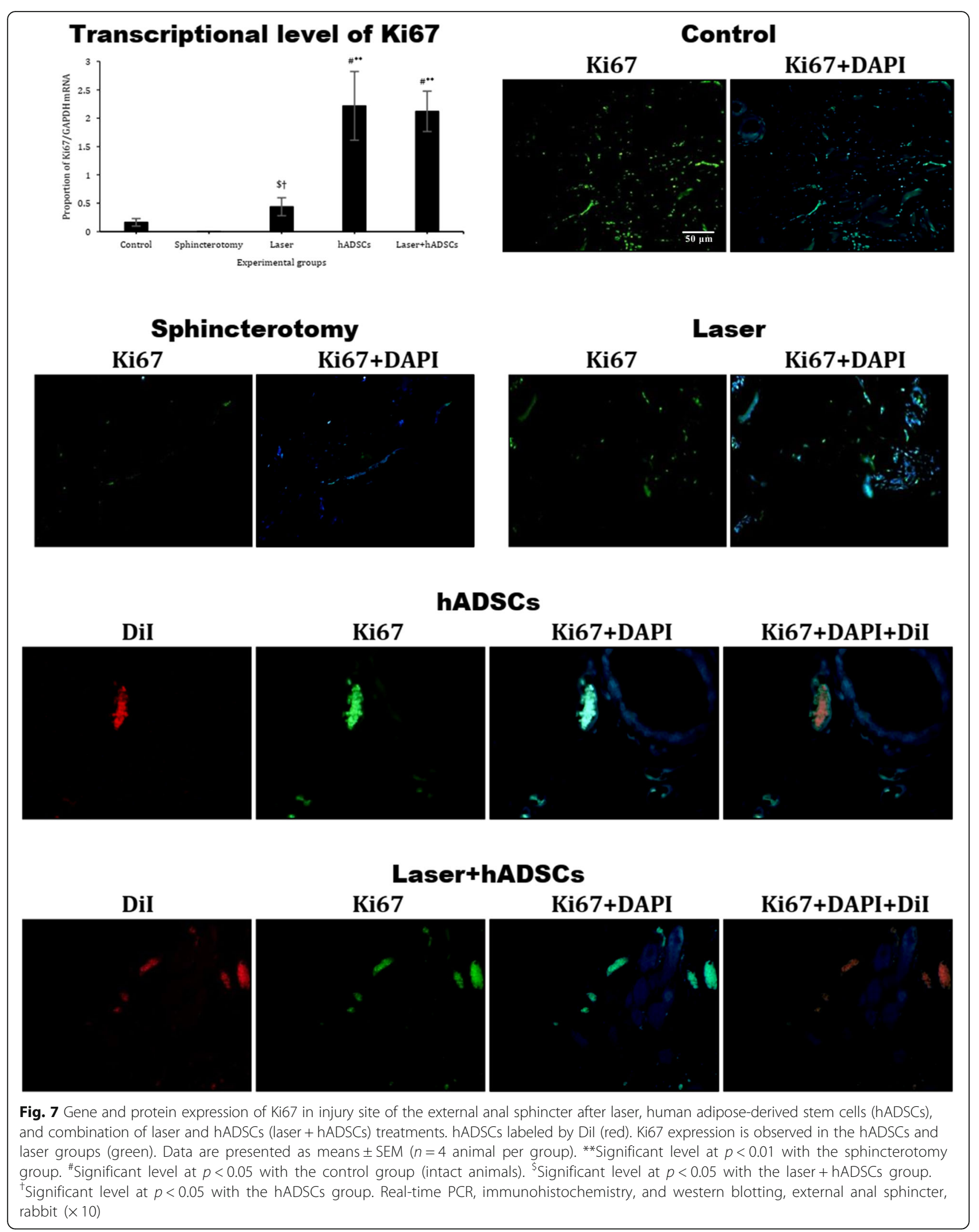


and maximum squeeze pressures were greatly decreased after sphincterotomy compared with the control group [25]. However, the resting pressure of the anal sphincter was improved with either laser or hADSC therapy, and it was more prominent in combination therapy. Laser treatment can induce muscle repair through satellite cell proliferation and differentiation [27], through increase in myofibril numbers [28], through anti-apoptotic [27] and anti-inflammatory [29] properties, and by stimulating angiogenesis [17]. Our results confirmed that laser therapy aids muscular repair via increased ki67 (proliferation factor) and VEGF mRNA gene expression compared with the sphincterotomy group. Mitochondria are recognized as the main photoreceptors within the cell, and the abundance of mitochondria in skeletal muscle (EAS) compared to smooth muscle (IAS) explains the different effects of laser therapy on the two sphincters [30]. Ehrreich et al. reported in 1968 that smooth muscle (other than vascular smooth muscle) exhibits very little sensitivity to visible and ultraviolet radiation [31]. This is consistent with our finding that resting pressure increase in the laser group is less than that in the hADSCs group. By contrast, hADSCs have the potential to repair both skeletal and smooth muscles, so the hADSCs group displayed higher resting pressure hADSCs compared with the laser group.

The fact that laser therapy promotes migration, proliferation, paracrine activity, and differentiation of hADSCs [32-34] explains why the combination therapy had a greater increase in resting anal pressure than hADSCs alone. Our immunohistochemistry and mRNA expression findings showed more expression of $\alpha$-actin and myosin heavy chain, in the combination group than the laser or hADSCs alone. Escalating effects of the laser on Ki67 and VEGFA expression could be due to their short half-lives ( 1 to $1.5 \mathrm{~h}$ [35] and 30 to $45 \mathrm{~min}$ [36] respectively). As a result, a difference in expression of these indicators of proliferative and paracrine activity might have been observed, if hADSC gene expression had been examined immediately after laser therapy at the end of the second week.

We found that the laser, hADSCs, and combination groups had increased maximum squeeze pressure compared with the sphincterotomy group, without any differences between them. The maximum squeeze pressure is the result of the EAS, despite of the resting pressure, which is the result of both EAS and IAS. There is no significant difference among the effects of the laser, hADSCs, and laser + hADSCs on EAS. If the maximum squeeze pressure (similar to the resting pressure) came from the contractility tone of the two muscles, the same results would be expected.

Our EMG findings showed that sphincterotomy dramatically decreased the number of motor unit numbers compared with the control animals, consistent with our observations of a high collagen content at the site of injury. The laser, hADSCs, and combination therapy groups showed a significant increase in motor units, consistent with a surge of myofibrils in the injured areas and a reduction in collagen content. Both Roth et al. and Weiss et al. demonstrated that injured areas of muscle were filled with new myofibrils capable of contractile activity [28, 37]; additionally, Shefer et al. showed that laser irradiation could stimulate the satellite cells near myofibrils and form new myofibrils for muscular repair [27]. Moreover, laser irradiation could modulate the collagen content in injured areas through nuclear factor kappa-B (NF-kB) gene expression, collagen I and III remodeling [38], and a reduction in collagen content in skeletal muscles [39]. Rodriguez et al. indicated that the hADSCs could repair a posterior tibialis muscle injury via formation and fusion of new myotubes [40]. Liu et al. ascertained that hADSCs express the myogenic biomarkers (MyoD, myogenin, and MYH) which could differentiate hADSCs to myotubes. They also showed the myotube fusions and hADSC contribution in muscular repair [41]. Pecan et al. demonstrated that hADSCs could increase myofibril numbers in injured areas. This results from both differentiation of hADSCs into myogenic lines and the activation, division, and differentiation of satellite cells through hADSC paracrine activity, including IGF-1, VEGF, and HGF secretion [42]. In addition to the myofibril formation at the site of the lesion, other paracrine activities of hADSCs (regulation of TGF- $\beta 1$ and TGF- $\beta 2$ via HGF secretion) have anti-fibrotic effects, reducing collagen deposition at the site of the muscle lesion $[23,43]$.

In our study, motor unit numbers in the combination group were higher than those in the laser treatment alone. This may be due to the additive effect of the laser and hADSCs on collagen content reduction and myofibril surge. In the hADSCs treated group, the motor unit number increased. It may be related to the role of stem cells in muscle healing, either differentiating into muscle cells, having anti-fibrotic effects, or promoting and facilitating satellite cell differentiation by other mechanisms [27-29]. The results of immunohistochemistry and gene expression markers for skeletal muscles (MHC and $\alpha$ actin) have confirmed these effects.

Along with the collagen synthesis, a key step in wound healing is the remodeling of collagen, in which the biomechanical properties of the scar are optimized [44]. Remodeling is usually initiated 2 to 3 weeks after injury and continues for more than 1 year [45]. Vimentin is an intermediate filament that is necessary for the collagen formation and remodeling in response to injury $[44,46]$. In the present study, the highest collagen and vimentin expression was seen in the sphincterotomy group, which 
may relate to vimentin's role in the remodeling of collagen. However, vimentin expression during the regeneration stage of the skeletal muscle is inversely proportional to the number of mature myofibrils. It means that intact skeletal muscle with myotube cross-linking and mature myofiber lacks vimentin expression [47]. In the present study, the strong reduction in vimentin expression in the laser, hADSCs, and combination groups may indicate mature myofibrillar replacement in the injured areas. The resting and maximum squeeze pressures, expression of specific skeletal muscle genes ( $\alpha$-actin and MHC), EMG, and collagen content assessment are consistent with a significant surge of mature myofibrils.

In our study, hADSCs were used. Some animal studies show that xenograft transplantation of mesenchymal stem cells can reduce the immunomodulation [48] and efficacy of these cells [49]. However, the use of hADSCs has been usual in preclinical studies [50-52] and its efficacy is proven. The findings of the present study also show that xenograft transplantation of hADSCs in the anal sphincterotomy model in rabbit improves sphincter function and tissue repair. It is recommended to compare the efficacy of xenograft and allograft transplantation of ADSCs in future studies.

A fourth-degree anal sphincter injury usually occurs after a vaginal delivery, iatrogenic injury, pelvic injury in a motor vehicle accident, or blast injury. hADSC preparation and transplantation is a time-consuming process. Therefore, the hADSCs could not be an ideal option for acute-phase injury. However, laser therapy is a noninvasive and more suitable method in acute anal sphincter injuries.

The range of light used in LLL ranges from 600 to $1070 \mathrm{~nm}$. The effect of different wavelengths of a laser varies depending on the site and depth of injury. In our sphincterotomy model, the skin, mucosa, and muscle were incised. According to the study of Chung et al. [53], the optimum laser wavelength in repairing superficial tissues is 600 to $700 \mathrm{~nm}$. Therefore, like many other articles on muscle repair [54-56], we used a $660-\mathrm{nm}$ laser. The reason for the selection of the $660-\mathrm{nm}$ wavelength is optimum efficacy in inflammatory processes, angiogenesis, fibroblast proliferation, and cytokine secretion, while such effects are not observed at higher wavelengths (940 and $808 \mathrm{~nm}$ ) [57].

Although we confirmed the survival of transplanted cells at the end of 90th day, the survival rate was not compared in the different groups and the effect of LLL on hADSC survival in the combination group was not clear. Laser is a non-invasive treatment compared to cell therapy. However, the effect of laser on some parameters such as anal sphincter resting pressure is less than that of hADSCs. We suggest that different protocols for laser irradiation including different durations of the laser irradiation in each session or shorter/longer wavelengths be studied in future trials. We measured the squeeze pressure when the probe was inserted into the animal rectum, and then we stimulated the external anal sphincter using the tingling method. Although recording squeezing pressure during EMG stimulation is a better method, we have used the tingling method to mimic a natural stimulus (such as coughing or striking the external anal sphincter) that causes squeeze pressure of the anal sphincter. Therefore, lack of a significant difference between the treated groups may be due to the method of squeeze pressure measurement. Overall, it seems that the measurement of squeeze pressure in animal studies is not reliable.

\section{Conclusion}

The present study indicates that co-application of laser and hADSC therapy immediately after anal sphincter damage could improve subsequent sphincter function. Moreover, combined therapy appears more effective for regaining resting anal pressure, and stimulating myogenesis and angiogenesis, than either laser or hADSCs alone.

\section{Supplementary information}

Supplementary information accompanies this paper at https://doi.org/10. 1186/s13287-019-1477-5.

Additional file 1: Table S1. Primer sequences for real time PCR. Figure S1. Flow cytometry of hADSCs. Morphology (fifth passage) (A) and cell surface markers (B-D) use for characterization of hADSCs (CD29+, CD73+, CD105+, CD34-, and CD45-).

\section{Abbreviations}

ACTA1: Skeletal muscle alpha-actin; EAS: External anal sphincter; EMG: Electromyography; GAPDH: Glyceraldehyde-3-phosphate

dehydrogenase; hADSCs: Human adipose-derived stem cells; LLL: Low-level laser; IAS: Internal anal sphincter; MUAP: Motor unit action potential; MYH: Myosin heavy chain; VEGF: Vascular endothelial growth factor A

\section{Acknowledgments \\ None}

Authors' contributions

$A S, M Y, C K R$, and $A B$ designed the study. $A S, A Y, M M$, and $A B$ gathered the data. MY analyzed the data. AS, SA, JS, and BM interpreted the findings. SA and $M Y$ wrote the first draft and other authors critically revised the manuscript. All authors read and approved the final manuscript.

\section{Funding}

This research was supported by grant no. 94-04-182-27064 from Iran University of Medical Sciences.

Availability of data and materials

The data that support the findings of this study are available from the corresponding author upon reasonable request.

Ethics approval and consent to participate

The study was approved by the ethics committee of Iran University of Medical Sciences (study code 94-04-182-27064). 


\section{Competing interests}

The authors declare that they have no competing interests.

\section{Author details}

'Colorectal Research Center, Iran University of Medical Sciences, Tehran, Iran. ${ }^{2}$ Liver and Digestive Research Center, Research Institute for Health Development, Kurdistan University of Medical Sciences, Sanandaj, Iran. ${ }^{3}$ Department of Anatomy, Faculty of Medicine, Alborz University of Medical Sciences, Karaj, Iran. ${ }^{4}$ Discipline of Medicine, University of Adelaide, Adelaide, SA, Australia. ${ }^{5}$ Centre of Research Excellence in Translating Nutritional Science to Good Health, University of Adelaide, Adelaide, SA, Australia. ${ }^{6}$ Neuromusculoskeletal Research Center, Department of Physical Medicine and Rehabilitation, Iran University of Medical Sciences, Tehran, Iran. ${ }^{7}$ Infectious and Tropical Diseases Research Center, Hormozgan Health Institute, Hormozgan University of Medical Sciences, Bandar Abbas, Iran. ${ }^{8}$ Physiology Research Center, Iran University of Medical Sciences, Tehran, Iran.

Received: 13 July 2019 Revised: 28 October 2019

Accepted: 30 October 2019 Published online: 02 December 2019

\section{References}

1. Floyd WF, Walls EW. Electromyography of the sphincter ani externus in man. J Physiol. 1953;122:599-609.

2. Browning GG, Motson RW. Anal sphincter injury. Management and results of Parks sphincter repair. Ann Surg. 1984;199:351-7.

3. Markland AD, Greer WJ, Vogt A, Redden DT, Goode PS, Burgio KL, Richter HE. Factors impacting quality of life in women with fecal incontinence. Dis Colon Rectum. 2010;53:1148-54.

4. Whitehead WE, Borrud L, Goode PS, Meikle S, Mueller ER, Tuteja A, Weidner A, Weinstein M, Ye W. Fecal incontinence in US adults: epidemiology and risk factors. Gastroenterology. 2009;137:512-7 517.e511-512.

5. Wexner SD, Marchetti F, Jagelman DG. The role of sphincteroplasty for fecal incontinence reevaluated: a prospective physiologic and functional review. Dis Colon Rectum. 1991;34:22-30

6. Bharucha AE, Zinsmeister AR, Locke GR, Seide BM, McKeon K, Schleck CD, Melton $L$. Prevalence and burden of fecal incontinence: a population-based study in women. Gastroenterology. 2005;129:42-9.

7. Goetz LH, Lowry AC. Overlapping sphincteroplasty: is it the standard of care? Clin Colon Rectal Surg. 2005;18:22-31.

8. Hung MJ, Wen MC, Huang YT, Chen GD, Chou MM, Yang VC. Fascia tissue engineering with human adipose-derived stem cells in a murine model: implications for pelvic floor reconstruction. J Formos Med Assoc. 2014;113:704-15

9. Wald A. Clinical practice. Fecal incontinence in adults. N Engl J Med. 2007; 356:1648-55.

10. Raghavan S, Gilmont RR, Miyasaka EA, Somara S, Srinivasan S, Teitelbaum DH, Bitar KN. Successful implantation of bioengineered, intrinsically innervated, human internal anal sphincter. Gastroenterology. 2011;141:310-9.

11. Yang XF, He X, He J, Zhang LH, Su XJ, Dong ZY, Xu YJ, Li Y, Li YL. High efficient isolation and systematic identification of human adipose-derived mesenchymal stem cells. J Biomed Sci. 2011;18:59.

12. Zuk PA, Zhu M, Mizuno H, Huang J, Futrell JW, Katz AJ, Benhaim P, Lorenz $\mathrm{HP}$, Hedrick MH. Multilineage cells from human adipose tissue: implications for cell-based therapies. Tissue Eng. 2001;7:211-28.

13. Beane OS, Fonseca VC, Cooper LL, Koren G, Darling EM. Impact of aging on the regenerative properties of bone marrow-, muscle-, and adipose-derived mesenchymal stem/stromal cells. PLoS One. 2014;9: e115963.

14. Bertolini F, Lohsiriwat V, Petit JY, Kolonin MG. Adipose tissue cells, lipotransfer and cancer: a challenge for scientists, oncologists and surgeons. Biochim Biophys Acta. 1826;2012:209-14.

15. Eom YW, Lee JE, Yang MS, Jang IK, Kim HE, Lee DH, Kim YJ, Park WJ, Kong $\mathrm{JH}$, Shim KY, et al. Effective myotube formation in human adipose tissuederived stem cells expressing dystrophin and myosin heavy chain by cellular fusion with mouse C2C12 myoblasts. Biochem Biophys Res Commun. 2011;408:167-73.

16. Cressoni MD, Dib Giusti HH, Casarotto RA, Anaruma CA. The effects of a 785-nm AlGalnP laser on the regeneration of rat anterior tibialis muscle after surgically-induced injury. Photomed Laser Surg. 2008;26: 461-6.
17. Nakano J, Kataoka H, Sakamoto J, Origuchi T, Okita M, Yoshimura T. Lowlevel laser irradiation promotes the recovery of atrophied gastrocnemius skeletal muscle in rats. Exp Physiol. 2009;94:1005-15.

18. Alexsandra da Silva Neto Trajano L, da Silva CL, de Carvalho SN, Cortez E, Mencalha AL, de Souza da Fonseca A, Stumbo AC: Cell viability, reactive oxygen species, apoptosis, and necrosis in myoblast cultures exposed to low-level infrared laser. Lasers in Medical Science 2016, 31:841-848.

19. Vinck EM, Cagnie BJ, Cornelissen MJ, Declercq HA, Cambier DC. Increased fibroblast proliferation induced by light emitting diode and low power laser irradiation. Lasers Med Sci. 2003;18:95-9.

20. Saygun I, Karacay S, Serdar M, Ural AU, Sencimen M, Kurtis B. Effects of laser irradiation on the release of basic fibroblast growth factor (bFGF), insulin like growth factor-1 (IGF-1), and receptor of IGF-1 (IGFBP3) from gingival fibroblasts. Lasers Med Sci. 2008;23:211-5.

21. Sarveazad A, Bakhtiari M, Babahajian A, Janzade A, Fallah A, Moradi F, Soleimani M, Younesi M, Goudarzi F, Joghataei MT. Comparison of human adipose-derived stem cells and chondroitinase $A B C$ transplantation on locomotor recovery in the contusion model of spinal cord injury in rats. Iran J Basic Med Sci. 2014:17:685-93.

22. Sarveazad A, Babahajian A, Bakhtiari M, Soleimani M, Behnam B, Yari A, Akbari A, Yousefifard M, Janzadeh A, Amini N. The combined application of human adipose derived stem cells and Chondroitinase $A B C$ in treatment of a spinal cord injury model. Neuropeptides. 2017;61:39-47.

23. Sarveazad A, Newstead GL, Mirzaei R, Joghataei MT, Bakhtiari M, Babahajian A, Mahjoubi B. A new method for treating fecal incontinence by implanting stem cells derived from human adipose tissue: preliminary findings of a randomized double-blind clinical trial. Stem Cell Res Ther. 2017:8:40.

24. Goudarzi F, Mohammadalipour A, Bahabadi M, Goodarzi MT, Sarveazad A, Khodadadi I. Hydrogen peroxide: a potent inducer of differentiation of human adipose-derived stem cells into chondrocytes. Free Radic Res. 2018; 52(7):763-74.

25. Sultan AH. Obstetrical perineal injury and anal incontinence. J Patient Saf Risk Manag. 1999:5:193-6.

26. Bansal N, Sachdeva M, Jain P, Ranjan P, Arora A. Anorectal manometry: current techniques and indications. JIMSA. 2013:26:169-70.

27. Shefer G, Partridge TA, Heslop L, Gross JG, Oron U, Halevy O. Low-energy laser irradiation promotes the survival and cell cycle entry of skeletal muscle satellite cells. J Cell Sci. 2002;115:1461-9.

28. Roth $\mathrm{D}$, Oron $\mathrm{U}$. Repair mechanisms involved in muscle regeneration following partial excision of the rat gastrocnemius muscle. Pathobiology. 1985:53:107-14

29. Liu X-G, Zhou Y-J, Liu TC-Y, Yuan J-Q. Effects of low-level laser irradiation on rat skeletal muscle injury after eccentric exercise. Photomed Laser Surg. 2009:27:863-9.

30. Park S-Y, Gifford JR, Andtbacka RH, Trinity JD, Hyngstrom JR, Garten RS, Diakos NA, Ives SJ, Dela F, Larsen S. Cardiac, skeletal, and smooth muscle mitochondrial respiration: are all mitochondria created equal? Am J Physiol. 2014;307:H346-52

31. Ehrreich SJ, Furchgott RF. Relaxation of mammalian smooth muscles by visible and ultraviolet radiation. Nature. 1968;218:682-4.

32. Yin K, Zhu R, Wang S, Zhao RC. Low-level laser effect on proliferation, migration, and antiapoptosis of mesenchymal stem cells. Stem Cell Dev. 2017;26:762-75

33. Mvula B, Mathope T, Moore T, Abrahamse H. The effect of low level laser irradiation on adult human adipose derived stem cells. Lasers Med Sci. 2008; 23:277-82.

34. de Villiers JA, Houreld NN, Abrahamse H. Influence of low intensity laser irradiation on isolated human adipose derived stem cells over 72 hours and their differentiation potential into smooth muscle cells using retinoic acid. Stem Cell Rev. 2011;7:869-82

35. Hosseini M, Yousefifard M, Baikpour M, Rafei A, Fayaz M, Heshmat R, Koohpayehzadeh J, Asgari F, Etemad K, Gouya MM. Twenty-year dynamics of hypertension in Iranian adults: age, period, and cohort analysis. J Am Soc Hypertens. 2015;9:925-34.

36. Shima DT, Deutsch U, D'Amore PA. Hypoxic induction of vascular endothelial growth factor (VEGF) in human epithelial cells is mediated by increases in mRNA stability. FEBS Lett. 1995:370:203-8.

37. Weiss $N$, Oron $U$. Enhancement of muscle regeneration in the rat gastrocnemius muscle by low energy laser irradiation. Anat Embryol (Berl). 1992;186:497-503 
38. de Souza TOF, Mesquita DA, Ferrari RAM, dos Santos PD, Correa L, Bussadori SK, Fernandes KPS, Martins MD. Phototherapy with low-level laser affects the remodeling of types I and III collagen in skeletal muscle repair. Lasers Med Sci. 2011;26:803.

39. Renno ACM, Assis L, Peres B, Rodrigues NC, Brunelli RD, Toma RL, Medalha CC, Ribeiro DA. The effects of low level laser therapy on injured skeletal muscle. Braz Arch Biol Technol. 2014;57:48-54.

40. Rodriguez A-M, Pisani D, Dechesne CA, Turc-Carel C, Kurzenne J-Y, Wdziekonski B, Villageois A, Bagnis C, Breittmayer J-P, Groux H. Transplantation of a multipotent cell population from human adipose tissue induces dystrophin expression in the immunocompetent mdx mouse. J Exp Med. 2005;201:1397-405.

41. Liu Y, Yan X, Sun Z, Chen B, Han Q, Li J, Zhao RC. Flk-1+ adipose-derived mesenchymal stem cells differentiate into skeletal muscle satellite cells and ameliorate muscular dystrophy in mdx mice. Stem Cells Dev. 2007;16:695-706.

42. Peçanha R, Ribeiro MB, Ferreira ABR, Moraes MO, Zapata-Sudo G, KasaiBrunswick TH, Campos-de-Carvalho AC, dos Santos Goldenberg RC, Werneck-de-Castro JPS. Adipose-derived stem-cell treatment of skeletal muscle injury. J Bone Joint Surg Am. 2012;94:609-17.

43. Jeong SR, Kwon MJ, Lee HG, Joe EH, Lee JH, Kim SS, Suh-Kim H, Kim BG. Hepatocyte growth factor reduces astrocytic scar formation and promotes axonal growth beyond glial scars after spinal cord injury. Exp Neurol. 2012;233:312-22.

44. LeBert D, Squirrell JM, Freisinger C, Rindy J, Golenberg N, Frecentese G, Gibson A, Eliceiri KW, Huttenlocher A. Damage-induced reactive oxygen species regulate vimentin and dynamic collagen-based projections to mediate wound repair. eLife. 2018;7:e30703.

45. Gonzalez AC, Costa TF, Andrade ZD, Medrado AR. Wound healing - a literature review. An Bras Dermatol. 2016;91:614-20.

46. Cheng F, Shen Y, Mohanasundaram P, Lindström M, Ivaska J, Ny T, Eriksson JE. Vimentin coordinates fibroblast proliferation and keratinocyte differentiation in wound healing via TGF- $\beta$-Slug signaling. Proc Natl Acad Sci U S A. 2016;113:E4320-7.

47. Vater R, Cullen MJ, Harris JB. The expression of vimentin in satellite cells of regenerating skeletal musclein vivo. Histochem J. 1994;26:916-28.

48. Lohan P, Treacy O, Morcos M, Donohoe E, O'Donoghue Y, Ryan AE, Elliman SJ, Ritter T, Griffin MD. Interspecies incompatibilities limit the immunomodulatory effect of human mesenchymal stromal cells in the rat. Stem Cells. 2018;36:1210-5.

49. Hosseini M, Yousefifard M, Aziznejad $H$, Nasirinezhad F. The effect of bone marrow-derived mesenchymal stem cell transplantation on allodynia and hyperalgesia in neuropathic animals: a systematic review with meta-analysis. Biol Blood Marrow Transplant. 2015;21:1537-44.

50. Goudarzi F, Sarveazad A, Mahmoudi M, Mohammadalipour A, Chahardoli R, Malekshah OM, Karimi Gorgani S, Saboor-Yaraghi AA. Combined effect of retinoic acid and calcium on the in vitro differentiation of human adiposederived stem cells to adipocytes. Arch Physiol Biochem. 2018;124:109-18.

51. Sarveazad A, Janzadeh A, Taheripak G, Dameni S, Yousefifard M, Nasirinezhad F. Co-administration of human adipose-derived stem cells and low-level laser to alleviate neuropathic pain after experimental spinal cord injury. Stem Cell Res Therapy. 2019;10:183.

52. Amini N, Vousooghi N, Hadjighassem M, Bakhtiyari M, Mousavi N, Safakheil H, Jafari L, Sarveazad A, Yari A, Ramezani S, et al. Efficacy of human adipose tissue-derived stem cells on neonatal bilirubin encephalopathy in rats. Neurotoxicity Res. 2016;29:514-24.

53. Chung H, Dai T, Sharma SK, Huang Y-Y, Carroll JD, Hamblin MR. The nuts and bolts of low-level laser (light) therapy. Ann Biomed Eng. 2012;40:516-33.

54. Alves AN, Fernandes KPS, Deana AM, Bussadori SK, Mesquita-Ferrari RA. Effects of low-level laser therapy on skeletal muscle repair: a systematic review. Am J Phys Med Rehabil. 2014;93:1073-85.

55. Rodrigues NC, Assis L, Fernandes KR, Magri A, Ribeiro DA, Brunelli R, Abreu DC, Renno ACM. Effects of $660 \mathrm{~nm}$ low-level laser therapy on muscle healing process after cryolesion. J Rehabil Res Dev. 2013;50(7):985-96.

56. Rodrigues NC, Brunelli R, de Araújo HSS, Parizotto NA, Renno ACM. Lowlevel laser therapy (LLLT)(660 nm) alters gene expression during muscle healing in rats. J Photochem Photobiol B: Biol. 2013;120:29-35.

57. Taradaj J, Shay B, Dymarek R, Sopel M, Walewicz K, Beeckman D, Schoonhoven L, Gefen A, Rosińczuk J. Effect of laser therapy on expression of angio- and fibrogenic factors, and cytokine concentrations during the healing process of human pressure ulcers. Int J Med Sci. 2018;15:1105-12.

\section{Publisher's Note}

Springer Nature remains neutral with regard to jurisdictional claims in published maps and institutional affiliations.

Ready to submit your research? Choose BMC and benefit from:

- fast, convenient online submission

- thorough peer review by experienced researchers in your field

- rapid publication on acceptance

- support for research data, including large and complex data types

- gold Open Access which fosters wider collaboration and increased citations

- maximum visibility for your research: over $100 \mathrm{M}$ website views per year

At BMC, research is always in progress.

Learn more biomedcentral.com/submissions 